\title{
AN EXTRAORDINARY SCHOOL TEACHER EXPERIENCE IN OVERCOMING GROWTH AND DEVELOPMENT OF CHILDREN WITH SPECIAL NEEDS
}

\author{
Yosephina Elizabeth Sumartini Gunawan1) , Maria Christina Endang Sukartiningsih2), Imelda Anita \\ Pandango ${ }^{3)}$ \\ 1),2) Health Polytechnic of Ministry of Health in Kupang \\ 3)Tanaringu Health Center West Sumba \\ Corresponding e-mail : bettytiang@gmail.com
}

\begin{abstract}
BACKGROUND : Children with special needs are children who in the proccess of growth or development experience abnormalities or deviations so as to require special treatment.

SUBJECT AND METHODE : This is qualitative study conduct with phenomeological approach. The participants were all teacher in Extraordinary Middle School in Waingapu. The data was obtained by structured interview and analyzed and presented in narrative form towards themes, sub themes, and categories found. This study was conduct to describe teacher's experience in overcoming the growth and development of childrena with special needs.

RESULTS : The themes obtained in this study were "the role of the teacher" and "the source of obstacles". The theme of the teacher's role sonsist of two subthemes, namely the teacher's role as an educator and the teacher's role as a motivator. The source of obstacle themes consist of 2 subthemes, namely students and teachers.

CONCLUSION : The role of the teacher as a motivator has been carried out in the form of of support, praise and reward but not doing touch. The results of research sources of obstacles from students are the limitations both physically and psychologically. Barriers from the teacher are lack of experience and feeling feel difficult and discouraged in dealing with students.
\end{abstract}

Key words : Experience, role of teachers, Extraordinary School Teachers, Children with Special Needs

\section{INTRODUCTION}

Normally each parent will enroll their child in the best choice school and leave the responsibility of educating their children to the teachers at the school, so that the teacher become the second parent of the child when they enter the school environment. Likewise for parents who have children with special needs, extraordinary schools are an option for parents inthe hope that their children get a proper education with a special approach. Children with special needs are children who are in the proccess of growth or development proccess who experience abnormalities or deviations (physical, mental, intellectual, social emotional), thus requiring special treatment. The diversity of developmental characters and barriers in children with special needs is konwn as mental retardation, hearing impairment and speech impairment, autism, physical impairment, unsociable, and visual impairment (Abdullah, 2013 in Nur Wulan Wati, 2018).

The teacher has an important role and also has guidance to be able to play a role in community and the school environment in a professional manner. Children with special needs have 
different characteristics from normal children, teachers must pay attention to them because they also deserve knowledge lika normal children. Teachers should not discriminate between them with normal children. Therefore the teacher's attitude is very important in dealing with children who have mental mental disorders, as we know for themselves that children who have mental disorders need support and motivation from those around them. The teacher's attitude is very influential on children with special needs. A teaches who teaches children with special needs must have a spirit of love for their students or be willing to accept the situation of students and value human values more than formal rules. The spirit of the teacher is expected to be able to make students not easily discouraged and do not feel inferior to their normal friends. If teachers are a little deviated from their thinking then they feel that no one really paya attention to them at school and makes their enthusiasm for learingn is dissapear. Teachers who teach children with mental disorders must really have patience and be able to recognize the child's character. Teacher solutions in overcoming child growth and development with special needs are responding to students feeling, using stident's ideas to carry out interactions that have been designed, dialogue and discuss with students, conformity between behavior and action, adjucting the contents of student's thinking frameworks, and smiling to students.

The data obtained from the Central Statistics Agency (BPS), stated that the number of children with special needs in Indoensia are reach 1.6 million children in 2017, and only 18 percent have received inclusive education services either from extraordinary school or ordianry schools implementing inclusive education. That is, one million more children with special needs have not received education that is important for their lives. The low number of children with special needs who educated was cused by various factors, ranging from the lack of adequate school infrastructure, the lack of special teaching staff, and also the community's stigma of childern with special needs. Based on data obtained from extraordinary junior high school at Waingapu the number of students in 2015 was 25 students, in 2016 were 20 students, and in 2017 there were 20 students divided into elementary, junior high school and senior high school. The number of teacher at extraordinary junior high school in Waingapu is 7 people.

Every teacher involved in learning activities is required to understand correctly, intactly and comprehensively about the potential contained in the human psychological structure as mentioned above. A teacher who does not master the human psycological structure will not only fail in carrying out his duties, but an act that is academically professional as an irresponsible act. Based on the description above, this research was conducted with the aim of obtaining a picture of the teacher's experience in overcoming the growth and development of children with special needs.

\section{METHODE}

This type of research is a qualitative research with phenomenological approach that provides an overview the experience special needs in Extraordinary Junior High School in Waingapu at 2018. Participants in this study were all teachers who teach in Extraordinary Junior High School in Waingapu. Data collection technicques used in this study were structured interviews conducted by researchers. Data were analyzed and presented in the form of narratives of the themes, sub themes, and categories found.

\section{RESULT}


This section consists of a description of the characteheristics of the participants and themes that emerge from the results of interviews conducted based on teachers's experience in overcoming the growth and development of children with special needs, as follows :

1. Participants characteristic

Participants in this study were five people. All participants are teachers who taech at Extraordinary Junior High School and have experience in overcoming the development of children with special needs in the working area of Extraordinary Junior High School East Sumba Regency. Characteristics of participiants cen be seen in the following table 1.

Table 1. Participants Characteristic in Extraordinary Junior High School in Waingapu (Primary Data, 2018)

\begin{tabular}{ccclc}
\hline \multirow{2}{*}{$\begin{array}{c}\text { Participant's } \\
\text { Code }\end{array}$} & \multicolumn{4}{c}{ Respondent's Characteristic } \\
\cline { 2 - 5 } & Age (years ol) & Gender & Educational degree & Employment Status \\
\hline 01 & 37 & male & Bachelor degree & Goverment employee \\
02 & 37 & Female & Bachelor degree & Goverment employee \\
03 & 28 & Female & Bachelor degree & Honorary employee \\
04 & 31 & Female & Bachelor degree & Honorary employee \\
05 & 31 & Female & Bachelor degree & Honorary employee \\
\hline
\end{tabular}

2. Theme analysis

The themes obatined in this study are "the role of teacher" and "the source of obstacle", which are described as follows :

\section{Theme 1 : Teacher's role}

The teacher's role theme consist of 2 sub themes namley the teacher's role as educator and teacher's role as a motivator. The sub-theme of educator consist of 2 categories namely giving general lessons and teaching independece, while the motivator sub-theme consist of 2 categories, namely giving praise, giving touch and giving a gift.

The following is the participants statement that confirms the teacher's role as an educator.

"when I see that they have not been well studied, I go up to them and ask what makes them noisy"(P1)

"after teaching I take the time to talk with them, so taht I get closer to them"(P2)

"in dealing with the growth and development of children with mental disorders no longer lay for us because we have long been a teacher at this school"(P3)

"....... with students studying in school and with good mentoring by teachers it is hoped that lessons can be well received"(P4)

"i hope they can learn back at home the subjects they have received at school and the ext day they can answer question"(P5) 
The following are participant sattements that empasize the teacher's role as a motivator.

"....well... always give motivation in the form of praise and reward to students who are ableto carry out the instruction from me. But I also do not forget to motivate students who have not been able to carry ot instructions from me so that they do not despair"(P1)

"... I applaud and applause for children who can carry out ny instructions and I also do not forget to give praise and I give encouragement to children who have not been able to carry out instruction from me"(P2)

“... I always give praise and support to them" $(P 3)$

"...I always give praise and reward to the children"(P4)

:.... give rewards to studenys whi can answer the questions I give" (P5)

"...I made a quiz and asked them "come on... who can answer rise your hand, who can answer will got the candy" $(P 3)$

"... for example, I gave an example of human needs and I asked to give examples of human needs, whi can answer even though it is not perfect yet, I still give rewards..." $(P 2)$

\section{Theme 2 :Source of obstacle}

The source of obstacle themes consist of 2 subthemes namely students and teachers. Subthemes of students consist of 2 chategories, namely physical diasbility of children and psychological disabilities of children, while the sub-theme of teachers consists of 2 categories, namely experience and feeling.

The following are participant statements taht confirm the source of the obstacles that come from students:

"....well the obstacles are conditional, for example, children are sulking, whiny and not in the mood... that's where the difficulty is, time is spent with that child..."(P1)

"....that's where the difficulty is, our time is up eith that child, because students in junior high school should be able to go to the toilet independently"(P2)

"....the obstacle is there are some students who do not want to write, because they are not in the miid, time is up with that child"(P3)

"....sometimes they don't want to go to the class and we have to be able to persuade them to go to the class"(P4)

"....well the obstacles are I must guide them to write and read"(P5)

The following is a prticipant statement that confirms the source of the obstacles that come from teacher : 
"....we find it a bit difficult in giving lessons in general, it must be individual. They need help because they have difficulty in writing and understanding..." (P1)

"during my teaching I always had difficulty dealing with students. They cannot keep quiet and always go in and out when I'm teaching"(P3)

\section{DISCUSSION}

Theme 1 : Teacher's Role

a. Educator (Lesson in General and Independency)

The resuts show teachers's role as an educator of five participants have different expectations where two participants said that the role as educator by giving approach to students of any conditions (P1 adn P2), while the other participants namley by their respective ways to provide lessons so the learning is acceptable to students and students can repeat it at home according to what is received by each student ( $P 3, P 4$, and $P 5)$.

The role of teachers as an educator is that a teacher not only educates and teach his students, but guides, provides guidance, role models, assisstance, training, understanding, skills, values, norm of decency, good and praiseworthy attitudes and so. In this case a teacher does not merely play a role as teaching staff who only carry out activities related to the transferof knowledge, but also act as an educator who transfers the values and at the same time as a supervisor who give direction and guides all students in more detail the duites of a teacher (Sardiman, 2005).

This research in in line with Ssardiman's theory in 2005. But the teacher's role as an educator is not as easy as given to the children with special needs. This is due to limiation of the studentsthemsleves both physically and psychologocally.

Research conducted by Dian Mardiana (2014) says that the teacher'role is not only as an educator but also as a demonstrator, motivator, mediator, facilitator, and evaluator. According to the researcher the role of a teacher as an educator in which the teacher provides instruction to students so that the knowledge posses by the teacher can be transferred to their students as expected. But giving instruction to the children with special needs is not as easy as we think. Viewed physically they are not as normal as other students, not to mention in certain cases there are students who are unable to be controlled properly so it is disturbing he learning proccess. This condition requires the role of a teacher who is not only an eduacator but is expected to be multi-role teacher figure. This is consistent with the results of the study that P1 and P2 said that the role of teachers as educators in children with special needs need to be approached according to their respective cases so that learning objectives can be achieved. Participants 3, P4 and P5 has their own way to providing teaching in accordance with the teacher's experience, this is in accordance with participants have Bachelor education. Teachers in extraodinary junior high school $n$ Waingapu are well prepared so that they already mastering the knowledge needed in their fields.

The teacher is prepared so that he can give good teaching in general and make the students become independent, it means that the students can carry out their learning task independently. Thus what is expected of a teacher as an educator can be achieved at an extarordinary junior high school. 
b. Motivator (Praise, touch, and gift)

The results of the study stated that the five participants doing their roles as motivators in their students by giving praise (P1, P2, P3,P4 and P5). While giving praise to students and giving rewards are participants of P3, P4, and P5. But none of them performed their role as motivators by touching the students.

The role of teacher as a motivator is important in order to increase the enthusiasme and development of students learning activities. Teachers must be able to stimulate and provide encouragement and to dynamize student potential, foster activity and creativity, so that there will be dynamics in the teaching and learming proccess. In the motto of education in Taman Siswa has long been known as "Ing Madya Mangun Karsa". The role of the teacher as a motivator is very important in teaching and learning interactions, because it involves the essence of the work of educating that requires social skills, in the sense of personalization and self socialization (Slameto, 1997).

This research is in accordance with research conducted by Dian Mardiana (2014) which say that the teacher's role as a motivator, they must show more of what is taught since children with mental retardation more often mimics what is done by their teacher.

Researcher also tough taht teacher's role as motivator is to give support or enthusiasm to the students in the learning proccess/ motivation carried out on both normal students or those with special needs is not much different. In children with special needs teacher are more likely to assist children when learning, teachers provide assistance to children when they face difficulties (Rahayu, 2017). This also in accordance with research conducted by Widuri (2013) that handles the interaction ability of social interaction namely learning activities and behavioral therapy given by the teacher.Being a motivator does not only encourage the students only, but the teachers also need to praise and giving a reward for the students who could accomplish the task. In a certain case, such as autism, motivation is not only given by praise or reward bit also by assisstance and touch that has to be done by the teacher.

\section{Theme 2 : source of obstacle}

a. Student (children physical disability and psychological disability)

Result study describing that children with special need is having an abnormal development, outomatically they are facing many obstacle in learning proccess. P1 said that her emotion is unstable so that she run out of time dealing with the children, P2 said that physical disability affect their ability to performing their basic need such as toileting independently. P3 and P4 said that the children refuse to write or read when they are studying, P4 said that the children refuse to entering the classroom, P5.

It is in line by theory explained by Sunardi and Suryono (2007) that student learning obstacle are came from internal and external factors so that they are fail to change an action becoming a cognitive shape with certain rules. Natawijaya (2005) said that learning obstacle is a situation caused an obstacle in applying theory when learning proccess is progressing. So that learning is important to understand since the learning obstacle could come into every class every children. Every children has the same possibilities to having this kind of 
obstacle. And children with special needs must have it too. Mudjito et al (2012) said that the present of children in inclusive school has to mastering their function and task better than an ordinary teacher.

This result is in line with the study conducted by Dayintha Galih Jalandhini (2017) said that the obstacle of children with special needs at the learning proccess is that they are feel the learning process is runs too fast and that make it difficult to understand. In this case, the deaf students can not foolow the learning proccess since they have no hearing aid tools. The deaf students has limitation in understading communication ande evironment suround them. Teh result study show the teacher are running out of time in handling thise children.

The children with special needs are difficult to understand the learning material since they have physical and psychological limitation, so it need more teachers to fulfill the standart rasio. So that the children with special needs will get served better. Teacher should be able to make curriculum arrangement and schedule that are felxible according to the study conducted by Suningsih and Arnidha (2017) because the limitation of children with special needs, that they can not understand auditory communicatoin from the environment.

As stated in articel 10 paragraph 1 of Ministry of Education Regulation NO 702009 explian that district/city goverment is required to provide at least 1 special titor in the education unit designated to carry out inclusive education. Thus problems that are related to children with special needs can be overcome because spesial advisors heve been equipped and prepared to deal with childern with special needs so that the obstacle related to students both pshysically and psychologically cen be handled properly.

b. Teacher (experience and feeling)

The results study show that the obstacles in learning process is not only come from the internal but also the external, namely the teacher. The teacher has different experience and feeling : some says that giving a lesson to the children with special needs is difficult, the lesson could not be teached generally, and the teacher should be understand their limitation (P1), it needs more patience handling children with special needs, they have many limitation... (P2). "During my teaching I always had difficulty dealing with the students. They cannot keep quiet and always go in and out when l'am teaching"(P3). ".......feeling annoyed and difficult to face them. Returning to think ou goals asa teacher and wants to teach and educate children with special needs...just enjoy it " (P4). "....there is a sense of despair handling children with special needs. One positive things that I can take that is learning how to be patience".

According to theGreat Indonesian dictionary ostacle have a very important meaningin carrying a task or a job. A task or a job will not be carried out if there is an obstacle that interferes with the work. Obstacle are circumstances that can cause implementation to be disrupted and not implemented properly, and therfore the obstacle experienced by participants in this study are teachers who experience conditional obstacles. This is in line with the explained by Purwodarminto (1996) states that conditions and situations that has been experineced (felt), carried out, and accounted for in real practice. The experience felt by teachers is reflected in the experience of feeling difficult when teaching students as expressed by participats (P1, P2,P3).

The study conducted by Dayinta Galih (2017) says that barriers experienced by inclusive teachers in SD Negeri Petir 2 include : 1) learning material that is not delivered in 
its entirety, 2) selection and use of learning startegies and methids that are appropriate for all students, 3) applicable asessmentpolicies, 4) curriculum modifications. This is consistenr with the results of research in which teachers find it difficut to give lessons to the children with special needs. Dian Mardiana's study in 2014 stated that the experienced of teachers in providing education to mentally diasbled students especu=ially the SDLB -C level required two teachers for one class because when using individual methodes of approach other students still get attention.

According to researcher, the external barriers of children with spescial needs are teachers, teacher play an impotant role in their learning process. The results tells about his experienced in wihch thd teacher feel dificulty in handling children with special need who are also limited in their ability to receove lessons in general. Feeling felt by the teacher also felt difficult and despair with different treatment. Therefore patience and commitment are needed in carrying out the role of children with special need. Quantitatively, it necessary to increse the number of teachers so that if teachers find it difficult to share with senior teachers who have a lit of experience with children with special needsnand find a way out, given the general data of participants, three of them are contract workers. Tehir experiences and feelings will be surely be different from those who have long been involved with chlidren with special needs.

\section{CONCLUSION}

Theme 1 : Teacher's Role

The result study show that teacher's role as an educator have not yet maximally made the children with special needs able to accept lessons delivered by the teacher. In carying out the role as an motivator the five respondents provided supoort, praise and rewars but all of them are not doing touch.

\section{Theme 2 : Source of Obstacle}

The results study shows that the obstacles are came from the students, namely limitation both physically and psychologically. Barriers from the teacher are the lack of experience and the sense of feel difficult anf discouraged in dealing with the children with special needs.

\section{REFFERENCE}

Afrizal,(2014). Metodologi Penelitian Kualitatif: Sebuah Upaya Mendukung Penggunaan Penelitian Kualitatif Dalam Berbagai Displin IImu. Penerbit PT Raja Grafindo Persada, Jakarta Alimul, Azis. (2005). Pengantar Ilmu Keperawatan Anak I. Jakarta: Salemba Medika.

Bayu Oktavianto, 2017, Peran Guru SLB Negeri Gedangan Dalam Menumbuhkan Kemampuan Literasi Informasi Siswa Disabilitas, Program Studi Ilmu Informasi dan Perpustakaan, Fakultas IImu Sosialdan IImu Politik, Universitas Airlangga, http://journal.unair.ac.id/downloadfullpapers-Ind8b264a9dffull.pdf 
Dayinta Galih Jalanidhi, 2017, Identifikasi Hambatan-Hambatan Guru Dalam Pembelajaran Di Sekolah Inklusif Sd Negeri 2 Petir Piyungan, Bantul, Jurnal Widia Ortodidaktika Vol 6 No 8, file://C:/Users/windows/Downloads/9784-21822-1-SM.pdf. diunduh pada tanggal 18 Agustus 2019, jam 10.18 wita.

Desliana Maulipaksi , 2017, Sekolah Inklusi dan Pembangunan SLB Dukung Pendidikan Inklusi, https://www.kemdikbud.go.id/main/blog/2017/02/sekolah-inklusi-dan-pembangunan-slbdukung-pendidikan-inklusi, 16/08/2019 10.50 wita

Dharma, (2011). Metodologi Penelitian Panduan Melaksanakan dan Menerapkan Hasil Penelitian. Penerbit: Trans Info Media, Jakarta

Dian Aulia citra Kusuma, 2019, Hasil penelitian berjudul "Pembelajaran Matematika Pada Anak Berkebutuhan Khusus (ABK) Di Sekolah Inklusi Kelas XI SMK" Surakarta, Universitas Mohammadiyah

Dian Mardiana, 2014, Hasil penelitian berjudul " Peran Guru dalam Proses Pembelajaran Anak Berkebutuhan Khusus (ABK) Tunagrahita, Jember, Universitas Jember.

Fajar Indra Septiana, Peran Guru Dalam Standar Proses Pendidikan Khusus Pada Lingkup Pendidikan Formal (Sekolah Luar Biasa/Sekolah Khusus), 2017, Inclusive: Journal of Special Education, Volume III Nomor 02 - Agustus 2017, file:///C:/Users/windows/Downloads/145-3021-SM.pdf, diunduh pada tanggal 18 Agustus 2019, jam 11.20 wita.

Jones, (1994). Faktor - faktor somatik, Atttention Defisit Hyperactivity Disorder. Jakarta: EGC Notoatmodjo. 2003. Pendidikan dan Perilaku Kesehatan, Jakarta : Rineka Cipta

Pusdatin Kemenkes RI, 2014, Infodatin: Penyandang Disabilitas pada Anak, file:///C:/Users/windows/Downloads/infodatin_disabilitas.pdf, diunduh pada tanggal 18 Agustus 2019, jam 11.50 wita.

Rochman Natawidjaja, Konseling Kelompok Konsep Dasar dan Pendekatan. Bandung: Rizqi, 2005 Rini Rahayu, 2017, Hasil Penelitian Berjudul "Peran Guru Dalam Mengembangkan Interaksi Sosial Anak Autis Di SD Al Firdaus", Surakarta, Universitas Mohammadiyah

Ratna Wahyu Widuri, 2013, Hasil penelitian Berjudul "Deskriptif Penanganan Interaksi Sugiyono. 2012. Metode Penelitian Kuantitatif dan Kualitatif. Bandung: Alfabeta.

Somantri, S. (2006). Psikologi Anak Luar Biasa. Bandung: PT. Refika Aditama.

Sosial Anak Autis Di Sekolah Anak Berkebutuhan Khusus Harapan Bunda Surabaya", Surabaya, Universitas Negeri Surabaya.

Suningsih dan Arnidha, 2017," Komunikasi Matematis Siswa Tunarungu Menggunakan Metode Pembelajaran Think pair Share". Js.fkip.ummetro.ac.id

Tika Anggreni Purba, 2019, 70 Persen Anak Berkebutuhan Khusus Tak Dapat Pendidikan Layak, https://lifestyle.bisnis.com/read/20190326/236/904431/70-persen-anak-berkebutuhan-khusustak-dapat-pendidikan-layak 16/08/2019 10.56 wita 